\title{
KEUNIKAN TEOLOGI KRISTEN DI ABAD XXI SEBAGAI QUEEN OF SCIENCES DI ERA POSTMODERN
}

\author{
Febriaman Lalaziduhu Harefa., M.Th
}

\begin{abstract}
Abstrak
Kecurigaan umat manusia terhadap bidang studi teologi Kristen pada abad XXI adalah tantangan baru bagi kekristenan masa kini. Orang menganggap bahwa teologi adalah sebuah bidang studi yang kuno dan telah hilang ketenarannya di dunia akademis. Memperhatikan hal di atas, maka dibuatlah penelitian untuk mengkaji ulang secara historis dan teologis tentang urgensitas bidang studi teologi di abad XXI. Untuk menemukan jawabannya, maka dibuatlah sebuah penelitian dengan pendekatan kualitatif dan menggunakan metode penelitian kepustakaan (library research). Hasilnya adalah teologi adalah jawaban atas segala "kegalauan" manusia tentang problematika kehidupan, teologi menuntun manusia memahami Allah Pencipta, teologi menjadi pedoman hidup manusia, teologi menuntun manusia memiliki kehidupan kekal dibalik kematian. Maka teologi adalah guru bagi ilmu pengetahuan (science), sehingga teologi wajib memberikan evaluasi terhadap ilmu pengetahuan (science) dengan cara intergrasi.
\end{abstract}

Kata Kunci : Teologi Kristen, Queen Of Science, Postmodern

\section{A. Pendahuluan}

Ilmu teologi adalah bidang studi ilmu, yang paling tua dari seluruh disiplin ilmu manapun. Keberadaanya telah ada, jauh sebelum seluruh disiplin ilmu pengetahuan ada. Akan tetapi dewasa ini, ilmu teologi terkesan "sedang punah" atau terkesan hampir "hilang dari peredaran", karena minimnya respon masyarakat postmodern atas eksistensinya. Selain itu kemajuan dan pengaruh ilmu pengetahuan (sciences) yang hampir merasuki seluruh sisi kehidupan umat manusia, menjadi salah satu faktor pemicu tertinggalnya atau hilangnya pengaruh bidang studi teologi. Dalam hal ini, Stevri I Lumintang berkomentar "tidak ada sisi terkecil pun dari kehidupan manusia tanpa dipengaruhi oleh ilmu pengetahuan. Semua bidang tidak luput dari manfat ilmu pengetahuan. Era demi era peradaban manusia sangat dipengaruhi oleh ilmu pengetahuan". ${ }^{1}$ Keadaan inilah yang melahirkan sebuah pemikiran bahwa ilmu teologi adalah bidang

1 Stevri I Lumintang, Theology The Queen Of Science \& The Master Of Philosophy, (Jakarta : Geneva Insani Indonesia, 2015), 1 
studi ilmu yang telah "kehilangan pengaruhnya" dan tidak patut lagi disebut sebagai ratu (queen) atas ilmu pengetahuan (sciences).

Mengapakah hal ini bisa terjadi?. Apakah hanya karena faktorfaktor di atas, maka minimnya minat masyarakat dewasa ini untuk mempelajari bidang studi teologi?. Apakah bidang teologi tidak lagi memiliki peranan dalam kehidupan umat manausia dewasa ini? Untuk memahami akan hal ini, memang harus dengan pikiran terbuka dan disertai dengan sikap kerendahan hati. Karena eksistensi teologi Kristen dewasa ini "seakan-akan bersembunyi" bukan karena hanya faktor pengaruh ilmu pengetahuan (sciences) dari pada ilmu teologi. Bukan juga karena kajian-kajian empiris dari ilmu teologi kurang mutahir (kuno). Bukan juga karena "Theos" yang hadir dalam studi teologi tidak mampu bertindak untuk melakukan kehendak-Nya bagi dunia ini. Sebenarnya, kelemahannya juga terletak pada manusianya (sang teolog), dimana para teolog dewasa ini telah banyak meninggalkan kasihnya yang mula-mula.

Dewasa ini doing theology hanyalah merupakan ekspresi dari kajian teologi bukanlah penebusan privat. ${ }^{2}$ Kajian-kajian ilmu teologi bukan lagi berbicara tentang apa yang menjadi kepentingan dan kehendak Allah bagi dunia serta rancangan Allah yang mulia bagi umat manusia. Tujuan teologi hanyalah semata-mata memuaskan keinginan umat manusia (antroposentrisme) dan lebih mementingkan dan menghormati kepentingan konteks dari pada kepentingan teks. Allah hanya semacam "gambar tempel" yang sengaja dipasang di dinding-dinding bangunan stuktural studi teologi, supaya dianggap Ia hadir dan merestui setiap kegiatan dalam studi teologi. Maka tidaklah heran jilakau kajian-kajian teologi tidak lagi menghasilkan kebenaran yang objektif, sebaliknya semua kebenaran hanya partikular, terbatas dan insuler. ${ }^{3}$ Manusia menjadi ukuran dalam mencari kebenaran (manusia adalah allah bagi dirinya sendiri), gaya hidup yang bebas berekspresi dengan mengikuti kata hati untuk mencapai konsumeristik, sektarianistik, komersialistik, hedonistik, dan pragmatistik. ${ }^{4}$

Selain hal di atas, faktor lain yang mempengaruhi hilangnya minat masyarakat modern terhadap studi teologi, juga terletak pada orang Kristen atau teolog itu sendiri. Penghargaan para teolog dan orang Kristen terhadap ilmu teologi sangat minim. Hal ini memang dipengaruhi oleh spirit zaman dewasa ini, dimana manusia lebih berorientasi dan memilih hal-hal yang bersifat instant. Mereka menilai

2 J.B. Banawiratma, Beberapa Tantangan Terhadap Usaha Berteologi Dewasa Ini, 89

${ }^{3}$ R. Albert Mohler, Jr, "The Intergrity Of The Evangelical Tradition and Challenge of the Postmodern Paradigm" dalam The Challenge of Postmodernism : An Evangelical Engagement, (ed., David S. Dockery : Grand Rapids : Baker, 2001), 71

${ }^{4}$ Ramly B. Lumintang, Bahaya Postmodernisme E Peranan Kredo Reformed,..., 38 
ilmu teologi hanya berbicara tentang konsep-konsep abstrak dan bukan hal-hal yang praktis dan menyentuh konteks kehidupan manusia masa kini. Manusia malas untuk melakukan studi reflektif tentang Allah dan karya-karya-Nya. Sehingga secara tidak langsung, manusia sedang atau telah menolak eksistensi Allah dalam hidupnya dan atas seluruh aktifitasnya. Konsekuensi logis dari hal ini adalah kemerosotan nilai-nilai moral dan absennya prinsip-prinsip spiritualitas Alkitabiah di dalam kehidupan umat manusia. Bahkan kemajuan ilmu pengetahuan dan teknologi (IPTEK) telah menjadi "berhala-berhala baru" bagi masyarakat dunia postmodern.

\section{B. Tinjauan Historis : Theology Is The Queen Of Sciences}

Fakta bahwa sesungguhnya dalam sejarah dunia dan sejarah gereja, bidang studi teologi sudah pernah menjadi ratu (queen) seluruh ilmu pengetahuan (sciences). Pernyataan teologi sebagai queen diproklamirkan oleh teolog gereja Katolik bernama Thomas Aquinas (1224-174). Ia menyatakan bahwa doktrin suci dari gereja Katolik adalah ratu dari seluruh ilmu pengetahuan. Tentu pernyataannya ini cukup mempengaruhi cakrawala berpikir masyarakat umum pada waktu itu (kaum scholasticisme) dan berasumsi bahwa semua aktifitas intelektual memiliki korelasi dengan eksistensi Allah. Mereka mengakui bahwa segala sesuatu dalam aktifitas ilmu pengetahuan, jawabannya terdapat dalam studi teologi. Standart yang digunakan dalam pendekatan kepada ilmu adalah Alkitab, karena Alkitab diyakini sebagai sumber satu-satunya kebenaran. ${ }^{5}$ Untuk mengarahkan tujuan-tujuan dari teologi tersebut, maka para teolog abad pertengahan membuat sebuah rumusan penting "semacam yelyel" untuk mengarahkan setiap orang tetap berada dalam rel kebenaran teologi itu sendiri. Maka muncullah sebuah istilah bahwa theology is taught by God, teaches of God and leads to God (teologi diajarkan oleh Allah, mengajarkan tentang Allah dan memimpin kepada Allah). Pernyataan ini memberikan sebuah pemahaman bahwa pada abad pertengahan, pada teolog dengan penuh kesadaran menempatkan Allah sebagai sumber teologi, pokok atau inti dari teologi dan subjek dari teologi itu sendiri. Dengan diproklamirkannya studi teologi sebagai queen of sciences, maka pada saat yang sama juga menegakkan posisi gereja sebagai king of sciences. Maka sangatlah

5 Stevri I Lumintang, Theology The Queen Of Science \& The Master Of Philosophy, ..,61 
mustahil pada waktu itu apabila disiplin ilmu pengetahuan (sciences) berdiri sendiri dan terlepas dari pengaruh otoritas gereja. ${ }^{6}$

Faktor inilah yang melatarbelakangi universitas-universitas di abad pertengahan berada di bawah asuhan dan manajemen gereja Khatolik. Hal ini terus menerus dilakukan selama beberapa abad, termasuk keterlibatan sebagian besar Biarawan dan Biarawati dalam mengembangkan pendidikan. Proses belajar mengajar diadakan dibeberapa katedral-katedral dan hal yang cukup unik adalah program studi pendidikan sebagian besar adalah ilmu teologi, hukum, seni dan medis (khususnya obat-obatan). Namun program studi yang paling digemari dan favorit adalah program studi teologi. ${ }^{7}$ Stevri I Lumintang menuliskan bahwa :

Universitas-universitas didirikan selain oleh pemimpinpemimpin gereja, juga oleh raja-raja dan pemerintah daerah. Beberapa tahun setelah Peter Abelardus, di Italia berdirilah universitas pertama atau tertua di dunia yakni universitas Bologna pada tahun 1158. Ahli hukum Bologna, yakni Irnerius (1067-1138) mengikuti pola pengajaran Peter Abelardus. Universitas Bologna mengadopsi piagam mengenai kebebasan akademik (constitution habita) tahun 1150 yang menjamin hak mahasiswa dan ilmu pengetahuan. Selanjutnya berdirilah universitas-universitas lain baik oleh raja seperti Universitas Naples Ferediko dan Universitas Charles di Praha, maupun pemerintahan daerah seperti Universitas Erfurt. ${ }^{8}$

Namun seiring dengan berjalannya waktu dan semakin berkembangnya universitas-universitas tersebut, dengan mengedepankan hakikat keilmuan sciences. Membuat universitasuniversitas tersebut memisahkan diri dari pengaruh gereja, dan lebih menyukai bidang studi umum. Bagi mereka studi teologi sudah tidak relevan lagi dan kehilangan superiotasnya. berikut :

Dalam hal ini, Christiady Cohen juga menjelaskan sebagai

Pada abad pertengahan, ada anggapan bahwa theology is the queen of sciences. Kemudian setelah filsafat mengalami perkembangan yang pesat (setelah renaissance dan aufklarung) muncul anggapan bahwa filsafat adalah induk dari semua cabang disiplin ilmu pengetahuan. Dalam zaman modern ini

${ }^{6}$ Henry M Morris, The Biblical Basic for Modern Science, (Grand Rapids : Baker, 1984), 25-26

7 Ibid,..., 62

8 Stevri I Lumintang, Theology The Queen Of Science $\mathcal{E}$ The Master Of Philosophy,...,62 
anggapan-anggapan tersebut sudah tidak relevan bahkan tidak benar. ${ }^{9}$

Semenjak saat inilah studi teologi mulai kehilangan pengaruhnya. Secara umum masyarakat mulai beralih "haluan" ke ilmu pengetahuan umum (sciences). Masyarakat pada umumnya, menjunjung tinggi dan menerima nilai-nilai yang terdapat dalam ilmu pengetahuan umum (sciences), dibandingkan dengan nilai kebenaran yang ada di dalam studi teologi. Sikap peralihan ini juga dibuktikan dengan reaksi beberapa ilmuan bahkan sebagian para teolog yang berusaha mengkonfrontasikan argumen-argumen Bapa-bapa Gereja dengan kebenaran mutlak yang terdapat di dalam Kitab Suci (Alkitab firman Allah). Maka usaha-usaha untuk mempertentangkan ilmu pengetahuan umum (sciences) dengan Alkitab pun terus digulirkan, tanpa ada sedikitpun "rasa takut" akan otoritas ilahi dibalik penulisan Alkitab.

Di sisi lain gereja juga terus menerus melakukan usaha untuk mempertahankan supremasinya tanpa mengoreksi hakikat dogma dan memberikan penilaian yang objektif terhadap pengajaran gereja. Maksudnya adalah dogma-dogma gereja yang selama ini diterima oleh gereja Katolik, apakah sesuai dengan prinsip-prinsip penafsiran yang benar (sesuai prinsip penafsiran hermeneutika Alkitabiah)?. Sikap eksklusif gereja Katolik ini mempengaruhi keputusankeputusan gereja itu sendiri. Oleh sebab itu, harus memang diakui, bahwa gereja dalam hal ini gereja Katolik sudah pernah melakukan kesalahan dalam hal kesalahan pengertian tentang ide dan kemajuan ilmu pengetahuan umum (sciences). Dimana gereja Katolik pernah mendominasi dan mendikte ilmu pengetahuan umum (sciences). Pusat kebenaran hanya ada di dalam gereja Katolik dan segala macam perkembangan dalam ilmu pengetahuan (sciences) harus sesuai dengan dogma yang sudah ditetapkan oleh gereja.

Oleh sebab itu, gereja Katolik bertanggung jawab terhadap penghukuman kepada Galileo Galile dengan teori heliosentris. ${ }^{10}$

${ }^{9}$ Christiandy Cohen, "Sains, Teknologi \& Kebudayaan", Jurnal Teologi Stulos Volume 10 Nomor 1 April 2011, Togardo Siburian (ed), (Bandung : STT Bandung, 2011), 1

${ }^{10}$ Galileo Galilei (lahir di Pisa, Toscana, 15 Februari1564 - meninggal di Arcetri, Toscana, 8 Januari1642 pada umur 77 tahun) adalah seorang astronom, filsuf, dan fisikawanItalia yang memiliki peran besar dalam revolusi ilmiah.Sumbangannya dalam keilmuan antara lain adalah penyempurnaan teleskop, berbagai pengamatan astronomi, dan hukum gerak pertama dan kedua (dinamika). Selain itu, Galileo juga dikenal sebagai seorang pendukung Copernicusmengenai peredaran bumi adalah bulat mengelilingi matahari dan matahari sebagai sistem tatasurya. butoi gata Akibat pandangannya yang disebut itu ia dianggap merusak iman dan diajukan ke pengadilan gereja Italia tanggal 22 Juni1633. Pemikirannya tentang bumi adalah bulat dan matahari sebagai pusat tata surya bertentangan dengan ajaran Aristoteles maupun keyakinan gereja bahwa bumi adalah datar dan pusat alam semesta. Ia dihukum dengan 
Dimana pandangannya berseberangan dengan teori geosentris yang sudah pernah dikemukakan oleh Ptolemeus, yang notabene teori ini diterima sebagai dogma oleh gereja Katolik. ${ }^{11}$

\section{Tinjauan Teologis : Theology Is The Queen Of Sciences}

Tugas utama dalam doing theologi di abad XXI adalah mengembalikan pemahaman tentang posisi ilmu teologi (reposisi theology) sebagai the queen of sciences. Hal ini sangatlah penting karena pemahaman seseorang tentang sesuatu hal, berakibat pada penilaian yang objektif terhadap hal tersebut. Dalam hal ini, David Traci menuliskan bahwa teologi harus meletakkan fondasi intelektual bagi agama Alkitab yang dipraktikkan. Teologi harus melayani komunitas para penafsir yang percaya bahwa Alkitab adalah saksi tindakan Allah dalam dunia ini dan dalam Firman-Nya, Yesus Kristus. Dalam reruntuhan zaman ini, interpretasi Alkitabiah merupakan alat terbaik untuk membangun kembali kebudayaan yang pada awalnya memang dibangun di atas Alkitab. ${ }^{12}$

Pada hakikatnya, teologi adalah refleksi kritis atau kegiatan berpikir serta bertindak tentang Allah, manusia, alam semesta yang mewujudkan nilai-nilai iman di dalam Tuhan Yesus Kristus seperti yang tertulis di dalam Alkitab firman Allah. ${ }^{13}$ Artinya, sentralitas dari kegiatan berteologi (doing theology) adalah Yesus Kristus sedangkan

pengucilan (tahanan rumah) sampai meninggalnya. Baru pada tahun 1992 Paus Yohanes Paulus II menyatakan secara resmi bahwa keputusan penghukuman itu adalah salah, dan dalam pidato 21 Desember 2008 Paus Benediktus XVI menyatakan bahwa Gereja Katolik Roma merehabilitasi namanya sebagai ilmuwan. Menurut Stephen Hawking, Galileo dapat dianggap sebagai penyumbang terbesar bagi dunia sains modern. Ia juga sering disebut-sebut sebagai "bapak astronomi modern", "bapak fisika modern", dan "bapak sains". Hasil usahanya bisa dikatakan sebagai terobosan besar dari Aristoteles. Konfliknya dengan Gereja Katolik Roma (Peristiwa Galileo) adalah sebuah contoh awal konflik antara otoritas agama dengan kebebasan berpikir (terutama dalam sains) pada masyarakatBarat.

${ }^{11}$ Claudius Ptolemaeus (90 - $168 \mathrm{M}$ ), adalah seorang ahli geografi, astronom, dan astrolog yang hidup pada zaman Helenistik di provinsi Romawi, Aegyptus. Ptolemaeus adalah pengarang beberapa risalah ilmiah, tiga di antaranya kemudian memainkan peranan penting dalam keilmuwan Islam dan Eropa. Yang pertama adalah risalah astronomi yang dikenal sebagai Almagest (dalam bahasa Yunani $\mu \varepsilon \gamma a ́ \lambda \eta \Sigma v ่ v t a \xi \iota S$ "Risalah Besar"). Yang kedua adalah Geographia, yang merupakan diskusi teliti mengenai pengetahuan geografi Helenistik. Yang ketiga adalah risalah astrologi dikenal sebagai Tetrabiblos ("Empat buku") di mana dia berusaha mengadaptasi astrologi horoskop ke filosofi alam Aristotelian. Ia juga melestarikan daftar raja-raja kuno, disebut "Kanon Ptolemaeus", yang penting bagi penelitian sejarah Timur Tengah.

12 David Tracy, The Analogical Imagination: Christian Theology and the Culture of Pluralism (New York: Crossroad, 1981),29-30. 1981), 91

13 John H Leith, Introduction to the Reformed Tradition (Atlanta : John Knox Press, 
dasar-dasar fundamental bangunan atau frame work theology adalah Alkitab firman Allah. Hal ini merupakan sesuatu yang paling mendasar dalam seluruh aktifitas kehidupan umat manusia, karena Tuhan Yesus Kristus dan Alkitab adalah penyataan khusus yang Allah sediakan untuk mengasihi umat manusia. Dengan demikian semua kegiatan dan aktifitas umat manusia dalam hubungannya dengan penyataan umum, harus tunduk dan diterangi oleh penyataan khusus. Stevri Lumintang menuliskan bahwa :

Dengan demikian, semua kebenaran, termasuk ilmu pengetahuan, hanya dapat dimengerti dan diselami secara penuh berdasarkan penyataan umum Allah. Penyataan umum pun hanya dapat dipahami dan diselami berdasarkan penyataan khusus, yaitu penyataan di dalam dan melalui Tuhan Yesus Kristus. Itu berarti ilmu pengetahuan, hanya dapat dipahami dan diselami sesungguhnya di dalam keyakinan kepada dan pengenalan akan Tuhan Yesus Kristus. ${ }^{14}$ Maka pada era postmodernisme di abad XXI ini, kekristen harus sadar akan kelemahan yang terjadi selama beberapa abad terakhir. Gereja harus mengembalikan teologi sebagai queen of science. Walaupun dalam hal ini gereja harus mengevaluasi pendekatanpendekatan yang pernah dipergunakan. Jangan sampai pendekatan yang dipergunakan sama atau menyerupai yang dilakukan oleh gereja pada abad-abad pertengahan. Gereja yang adalah pusat teologi harus menjadi solusi bagi problematika konteks dunia masa kini bahkan solusi pada perkembangan serta problematika ilmu pengetahuan umum (sciences). Gereja jangan mempertahankan gengsi spriritualnya yang naif, tanpa terlebih dahulu melakukan tugas verifikasi, validasi dan interpretasi data-data teks Alkitab (hermeneutika Alkitabiah), dan mengkorelasikannya dengan kebutuhan konteks masa kini. Gereja bukan tunduk kepada konteks ilmu modern atau kebutuhan konteks tetapi, "lebih terbuka" terhadap kemajuan ilmu pengetahuan dengan menyaringnya dengan nilai-nilai yang tertulis di dalam Alkitab firman Allah. Maka Joseph Pohle menuliskan beberapa alasan mengapa teologi harus menjadi the queen of sciences, sebagai berikut:

Pertama, From its immanent dignity. while the secular sciences have other guide than the flickering lamp of human reason, theology is based upon faith, which, both objectively as revelation and subjectively as grace, is an immediate gift of God. Kedua, From its ulterior object. The secular sciences, apart from the gratification they afford to man's natural curiosity and love of knowledge, aim at no other end than that of shaping his earthly life, beautifying it and perhaps perfecting his 2006), 35

14 Stevri I Lumintang, Theologia \& Misiologia Reformed, (Batu : Literatur YPPII, 
natural happiness. While theology, on the other hand, guides man's, in all his different modes of activity, including the social and the political, to a supernatural end, whose delights "eye hath not seen, nor ear heard". Ketiga, From the certitude which it ensures. The certitude of faith, upon which theology bases all its deductions, a certitude that is rooted in the inerrancy of divine reason. Rather than in the participated infallibility of a finite and consequently fallible mind, excels even that highest degree of human certitude which is within the reach of metaphysics end mathematics. ${ }^{15}$

Bagi penulis sendiri, ada beberapa alasan mengapa teologi disebut the queen of sciences, sebagai berikut. Pertama, sudi teologi mampu menjelaskan dan menguraikan secara jelas tentang karya Allah yang besar seperti peristiwa penciptaan, providensia Allah atas alam semesta, inkarnasi Tuhan Yesus Kristus, dll. Bahkan studi teologi mampu memberi gambaran tentang keadaan ciptaan sebelum dunia dijadikan dan mampu menguraikan fakta kehidupan dibalik kematian dan masa yang akan datang (eskhatologis). Sedangkan ilmu pengetahuan umum (sciences) hanya memiliki akses untuk menyelidiki dan mengembangkan apa yang kelihatan dan ada pada masa kini (bersifat empiris). Ia tidak mampu menguraikan tentang keadaan hidup sebelum dunia ini diciptakan oleh Allah. Ilmu pengetahuan umum (sciences) tidak mampu menyelidiki bagaimana cara dan sistem Allah menciptakan alam semesta berserta isinya. Demikian juga tidak mampu memberikan gambaran tentang surga yang Allah sediakan kepada orang percaya. Arsitek terhebat pun tidak mampu memberi gambaran tentang konstruksi rumah Bapa seperti tertulis di dalam Yohanes 14:1-14. Maka Stevri I Lumintang menegaskan "ilmu pengetahuan adalah terbatas karena hanya bergantung pada proses berpikir kognitif dan prosedur dengan menggunakan metode penelitian. Padahal proses berupa aktifitas berpikir bukanlah tanpa kelemahan dan metode penelitian yang digunakan pun bukan tanpa keterbatasan dan manipulasi". ${ }^{16}$ Namun seorang teolog mampu memahami akan hal itu, karena ia mau menerima akan hal itu dengan iman dan memahaminya sebagai sebuah kebenaran.

Kedua, teologi mampu menguraikan hal-hal yang besifat supranatural seperti yang tercatat di dalam Alkitab. Perdebatan sengit dalam sejarah keilmuan adalah penjelasan yang konkrit dan komprehensif tentang hal-hal di luar akal manusia. Ilmu pengetahuan umum (sciences) lebih menerima filsafat rasionalisme, filsafat

${ }^{15}$ Joseph Pohle, God: His Knowability, Essence And Attributes A Dogmatics Treatise, (Freiburg : Aeterna Press, 2015), 201

16 Stevri I Lumintang, Theology The Queen Of Science \& The Master Of Philosophy,...,55 
empirisme atau filsafat eksistensialisme sebagai presuposisi keilmuannya. Ilmu pengetahuan umum (sciences) tidak memberikan porsi iman dalam menentukan validasi datanya. Sebagai contoh, para ilmuan pasti meragukan tentang keabsahan data Alkitab tentang kisah Yesus Kristus berjalan di atas air sesuai dengan kesaksian Matius 14:22-32. Kisah ini bertentangan hukum Archimedes yang mengatakan bahwa pada saat manusia berjalan atau berlari di dalam air, manusia tentunya akan merasakan bahwa langkahnya lebih berat dibandingkan jika melangkah di tempat biasa. Gejala ini disebabkan adanya tekanan dari zat cair. Jika sebuah benda dicelupkan ke dalam zat cair, maka benda tersebut akan mendapat gaya yang disebut gaya apung (gaya ke atas) sebesar berat zat cair yang dipindahkannya. Akibat adanya gaya apung, berat benda dalam zat cair akan berkurang. Benda yang diangkat dalam zat cair akan terasa lebih ringan dibandingkan diangkat di darat. Jadi, telah jelas bahwa berat benda seakan berkurang bila benda dimasukkan ke dalam air. Hal itu karena adanya gaya ke atas yang ditimbulkan oleh air dan diterima benda.

Dengan demikian maka resultan gaya antara gaya berat dengan gaya ke atas merupakan berat benda dalam air. Selanjutnya berat disebut dengan berat semu yaitu berat benda tidak sebenarnya karena benda berada dalam zat cair. ${ }^{17}$ Masih banyak hal-hal yang tertulis di dalam Alkitab yang mungkin berseberangan dengan disiplin ilmu pengetahuan umum (sciences). Semuanya itu tidak akan mampu dijelaskan melalui pengalaman dan logika manusia biasa. Para ilmuan adalah ciptaan Allah yang terbatas dengan demikian memiliki keterbatasan memahami karya-karya Allah yang tidak terbatas itu.

Bidang studi teologi juga dikembangkan secara keilmuan oleh teolog yang adalah manusia ciptaan yang memiliki banyak keterbatasan juga. Tetapi mengapa mampu memahami hal-hal yang supranatural dari Allah?. Ini bukan berbicara mengenai masalah "kemampuan atau kecerdasan intelektual saja", tetapi hal ini juga berhubungan dengan kecerdasan spiritual dan kecerdasan emosional yang telah diubahkan oleh Yesus Kristus. Rasul Paulus pernah memberi penegasan bahwa "sebab yang bodoh dari Allah lebih besar hikmatnya dari pada manusia dan yang lemah dari Allah lebih kuat dari pada manusia (1 Korintus 1:25)". Ternyata kuatannya terletak pada Allah yang berkenan memberi kemampuan kepada manusia (teolog). Maka sangatlah diperlukan kerendahan hati untuk datang kepada Allah Tritunggal, sehingga Ia dalam kedaulatan-Nya memberikan hikmat kepada teolog untuk memahami kehendak-Nya secara benar baik penyataan umum maupun penyataan khusus. Dengan demikian, tidak ada prinsip-prinsip ilmu pengetahuan umum (sciences) yang bertolak 
belakang dengan prinsip-prinsip Alkitab. Karena keduanya dinyatakan oleh Allah kepada manusia, agar manusia mengenal dan mempermuliakan Dia di surga.

Ketiga, ilmu teologi yang bersumber dari Alkitab firman Allah memiliki kemampuan untuk menguraikan tentang penyataan umum dan penyataan khusus. Dalam bahasa Yunani, penyataan adalah apokalupsis (dari apokalypto) yang artinya sesuatu yang disingkapkan (dibukakan) dari apa yang dahulu samar-samar, tertutup dan tidak terlihat jelas (Lukas 10:21 \& Efesus 3:5). Dalam bahasa Ibrani ada padanan arti dari pengertian di atas, yaitu gala, artinya telanjang (Keluaran 20:26, Yesaya 53:1, 2 Samuel 7:27). Maka penyataan adalah suatu tindakan Allah (baik itu perbuatan maupun kata-kata) yang adalah inisiatif Allah sendiri untuk membuka Diri agar manusia yang adalah ciptaan itu dapat mengenal Allah Penciptanya (1 Korintus 2:11 \& Ulangan 29:29). Bidang studi teologi membahas dan menguraikan tentang penyataan umum (general revelation) dan penyataan khusus (special revelation)..$^{18}$ Kedua penyataan Allah itu merupakan dua cara Allah menyingkapkan diri-Nya kepada manusia. Wahyu umum merujuk pada kebenaran-kebenaran umum tentang Allah, yang diketahui melalui penciptaan alam semesta. Wahyu khusus merujuk pada kebenaran yang lebih spesifik tentang Allah, yang diketahui melalui Tuhan Yesus Kristus dan Alkitab firman Allah. ${ }^{19}$ Gerrit Reimer menuliskan hal-hal yang termasuk dalam penyataan umum adalah alam semesta, sejarah dunia dan hati nurani. ${ }^{20}$

Ruang lingkup ilmu pengetahuan umum (sciences) hanyalah sebatas pada penyataan umum saja. Ia tidak memiliki kapabilitas memahami hal-hal supranatural dari wahyu khusus. Ilmu pengetahuan umum (sciences) tidak mampu membuktikan secara biologis tentang asal mula manusia pertama (Kejadian 1:26) dan proses kelahiran Tuhan Yesus Kristus dari seorang perawan Maria (Matius 1:18-25 \& Lukas 2:1-7). Tidak mampu menemukan alat atau metodologi untuk menciptakan dunia baru beserta isinya, seperti yang Allah Tritunggal kerjakan dalam Alkitab (Kejadian 1). Bahkan, ilmu

18 Penyataan atau Wahyu dalam bahasa Indonesia dikenal dengan istilah penyataan sering diartikan sama dengan kata wahyu. Kedua kata ini sebenarnya mempunyai konotasi yang berbeda. Dalam agama-agama lain kata wahyu diartikan sebagai pengetahuan yang didapat seseorang pada dirinya sendiri dengan keyakinan penuh bahwa pengetahuan itu datang dari Allah, baik dengan perantaraan atau tidak (mis.: mimpi, penglihatan, bisikan hati, dll.). Jadi berbeda sekali dengan pengertian yang diberikan dalam agama Kristen. Oleh sebab itu, istilah yang dipakai dalam tulisan ini adalah penyataan dan bukan wahyu.

${ }^{19}$ Louis Berkhof, A Summary Of Cristian Doctrine, (Edinburgh : Wm.B.Eerdmans Publishing Co, 1974), 11-15 $X X I, \ldots, 75$

${ }^{20}$ Gerrit Riemer, "Wahyu, Firman Allah \& Dogma", di dalam Bertheologi Abad 
pengetahuan umum (sciences) tidak memiliki kemampuan untuk membangkitkan orang mati seperti yang dilakukan Tuhan Yesus Kristus (Matius 9:18-26, Markus 5:21-43 \& Lukas 8:40-56) dan masih banyak lagi hal-hal supranatural tercatat di dalam Alkitab firman Allah. Peristiwa-peristiwa tersebut terkadang bertentangan dengan rasio manusia dan hukum-hukum yang diakui dalam ilmu pengetahuan. Ilmuan hanya mampu menemukan jawaban itu melalui iman saja (Ibrani 11:1-2). Karena ilmu pengetahuan umum (sciences) sangatlah terbatas memahami Allah dan karya-karya-Nya yang tidak ada batasannya.

Bidang studi teologi mampu memahami hal-hal supranatural tersebut karena didasarkan kepada presuposisinya, yang menempatkan iman kepada Allah Pencipta dan Alkitab adalah sumber otentik keilmuan. Rasio manusia tunduk di bawah pimpinan Roh Kudus dan otoritas iman dan tidak bermaksud untuk mendikte kebenaran mutlak yang tertulis secara sistematis di dalam Alkitab firman Allah. Sistem kerja inilah yang memingkinkan teologi memahami secara spesifik baik penyataan umum (alam semesta, hati nurani dan sejarah) dan penyataan khusus (Alkitab dan Tuhan Yesus Kristus), secara baik dan benar. Hal ini membawa teolog tidak mempertentangkan antara ilmu pengetahuan umum (sciences) dengan prinsip-prinsip kebenaran yang tertulis di dalam Alkitab. Bahkan sebaliknya, memahami hubungan satu dengan yang lainnya dan membawanya pada satu prinsip intergasi baik theologi maupun ilmu pengetahuan umum (sciences).

Keempat, metodologi dalam studi teologi diuji oleh Alkitab itu sendiri (Sui Ipsius Interpretes). Istilah sui ipsius interpretes adalah istilah yang muncul sejak terjadinya reformasi dalam rangka mengembalikan posisi Alkitab firman Allah pada posisi yang sesungguhnya (sola scriptura). Dalam hal ini para tokoh reformator menempatkan Alkitab kembali kepada pusat teologi dan kehidupan gereja, yaitu suatu kedudukan yang ditempatinya pada masa-masa sebelumnya. Mereka dengan segala macam daya upaya membebaskan Alkitab dari tafsiran subjektif gereja (paus dan rohaniwan gereja roma Katolik), sehingga maknanya aslinya tidak mampu dipahami dan diterima oleh orangorang percaya. Para reformator memegang suatu prinsip bahwa segala pengertian dan penjelasan Alkitab harus dicocokkan dengan analogi iman. Yakni pengajaran yang seragam dari Alkitab (omnis intellectus acexposito scripturae sit analogi fidei). Analogi iman adalah aturan yang menegaskan bahwa Alkitab harus menafsirkan Alkitab (sacra scriptura 
sui interpres). ${ }^{21}$ Artinya, jikalau ada keraguan ataupun problematika dalam proses penelitian (metodologi), maka seharusnya mencari jawabannya pada bagian lain dari kitab-kitab yang ada di dalam Alkitab (66 kitab dalam Alkitab). Dalam hal ini, teolog tidak diijinkan membuat simpulannya sendiri, karena Allah dalam kedaulatan-Nya telah mencurahkan seluruh isi hatinya di dalam Alkitab firman Allah. Metodologi ini memungkinkan menghindari penafsir dari praktik penyelewengan makna teks itu sendiri. Tetapi menjunjung tinggi nilainilai makna yang terkandung dalam teks Alkitab itu sendiri.

Kelima, ilmu teologi membimbing manusia untuk mengenal pencipta-Nya dan memberikan kontribusi untuk langkah hidup manusia di masa yang akan datang. Allah merelakan diri-Nya untuk dikenal oleh umat manusia. Pengenalan akan Allah ini membawa hidup manusia tetap berada pada jalur kebenaran dan hidup yang kekal. Maka mempelajari theologi sebenarnya memberikan kesejukan jiwa bagi manusia dan membawa kedamaian bagi dunia. Tidak pernah ada kabar, jikalau konsekuensi belajar theologi akan menghancurkan dunia dan sesama. Tetapi banyak kabar yang didengar belajar kimia dan mampu membuat bom dapat menghancurkan sesama. Belajar manajemen keuangan, manusia semakin pintar untuk korupsi. Tentu hal ini disebabkan karena para ilmuan tidak menerima ilmu yang ditekuni sebagai panggilan Allah, melainkan menggunakannya untuk mencari keuntungan. Namun sebaliknya, jikalau para ilmuan memahami maksud Allah dibalik ilmu pengetahuannya, maka pasti dia akan memelihara dan menegakkan rasa tanggung jawabnya dihadapan Allah dan manusia. Artinya, ia mengembangkan ilmu untuk kepentingan Allah demi kesejahteraan umat manusia.

\section{Keunikan Teologi Kristen Abad XXI}

Memperhatikan argumen di atas, baik argumen historisnya dan argumen teologis maka dapatlah dipahami bahwa bidang studi teologi adalah relevan dalam konteks zaman manapun. Sekaligus memberikan petunjuk bahwa bidang studi teologi tidak berseberangan dengan bidang studi pengetahuan umum (science). Bahkan teologi memberikan informasi yang sistematis, otentik dan komprehensif tentang kebenaran di seluruh sisi kehidupan manusia (universal). Dalam hal ini, Stevri I Lumintang menuliskan bahwa "teologi menjelaskan atau mengajarkan kebenaran (pengetahuan)

${ }^{21}$ Hasan Sutanto, Hermeneutik : Prinsip \& Metode Penafsiran Alkitab, (Malang : SAAT, 1998), 69 \& Sidney Greidanus, Preaching Christ From The Old Testament, (Bandung : Kalam Hidup, 2009), 168 
sehingga diterapkan dan dialami oleh umat (theology is taught by God, teaches of God and leads to Gos)". ${ }^{22}$ Sehingga penerapan bidang studi teologi bukan hanya berbicara hal-hal yang supranatural saja, melainkan menguraikan hal-hal praktis yang dapat dipahami oleh semua orang secara umum (universal).

Jikalau dalam perjalanan sejarah ditemukan ketidakcocokan, itu terjadi karena ketidakmampuan manusia atau teolog dalam memahami kebenaran Allah yang termuat dalam Alkitab. Karena ekspresi ilmu yang dituangkan dalam bidang studi teologi adalah hasil interpretasi dari Alkitab firman Allah. Dalam hal ini, Stevri I Lumintang menegaskan bahwa :

Pada satu sisi, teologi adalah ilmu pengetahuan (science), namun di sisi lain, teologi juga melampauhi ilmu (ascience), teologi tidak hanya berkenan dengan hukum alamiah (alam) melainkan juga berkenan dengan hukum supra-alamiah (Allah). ${ }^{23}$

Oleh sebab itu, bidang studi teologi mewarnai pemaknaan akan kebenaran Allah di dalam Alkitab dan pengalaman hidup bersama dengan Tuhan. Maka dalam dalam prosedur penelitian, teologi Kristen juga memiliki metode penelitian ilmiah sebagai ilmu. Seperti dituliskan oleh Stevri I Lumintang dalam bukunya Theology The Queen Of Science \& The Master Of Philosophy, bahwa :

Metode teologi sebagaimana yang telah disinggung sebelum ini, sama dengan ilmu pengetahuan ilmiah, menggunakan salah satu dan/atau kedua-dua pendekatan berikut ini, yakni pendekatan kuantitatif dan kualitatif. Pendekatan kuantitatif dengan paradigma positivistik atau scientifik (paradigma ilmiah), yang lebih sesuai untuk penelitian murni theologia praktika (terapan) seperti theologia pastoral, konseling, pendidikan kristen, misiologi dan teologi terapan lainnya sesuai dengan latarbelakang masalah dan variabel-variabelnya. Sedangkan pendekatan kualitatif paradigma naturalistik, lebih sesuai dengan penelitian theologia biblika, historika, sistematika, filosofika dan praktika, secara khusus sangat sesuai dengan theologia intergratif, baik antar bidang studi theologia maupun antara theologia dengan ilmu pengetahuan. ${ }^{24}$

Maka keunikan teologi untuk menjawab tantangan abad XXI. Pertama, teologi adalah jawaban atas segala "kegalauan" manusia Philosophy, ...,31

22 Stevri I Lumintang, Theology The Queen Of Science \& The Master Of

${ }^{23}$ Stevri I Lumintang, Theologia Reformasi Gereja Abad XXI, (Jakarta : Geneva Insani Indonesia, 2017), 313

24 Stevri I Lumintang, Theology The Queen Of Science \& The Master Of Philosophy,...,31-32 
tentang problematika kehidupan yang kompleks pada masa kini. Teologi mampu memberikan jawaban yang pasti terhadap problematika tersebut sebagaimana tertulis di dalam Alkitab firman Allah (Maz.119:105). Kedua, teologi menuntun umat manusia memahami Allah Pencipta (Kej.12:1-3). Ilmu pengetahuan terbatas memberikan informasi yang cukup tentang Sang Pencipta. Ilmu pengetahuan hanya mampu memberikan informasi yang jelas tentang ciptaan Allah, yaitu manusia dan alam semesta. Ketiga, teologi menjadi pedoman paling dasar atas semua sisi kehidupan manusia, etika kehidupan dan kebudayaan umat manusia (2Tim.3:16). Keempat, teologi dapat menuntun umat manusia untuk memiliki kehidupan kekal dibalik kematian. Kajian-kajian ilmu pengetahuan tidak mampu mengkaji tentang hal ini, karena ia tidak memiliki akses ke sana. Ia tidak memiliki referensi yang kuat sebagai dasar berpijak. Sedangkan teologi mampu melakukannya karena ia memiliki dasar berpijak yang final dan absolut yaitu Alkitab firman Allah.

Maka dalam perjalanannya, ilmu pengetahuan (science) dan teologi haruslah bekerja sama (intergrasi). Tidaklah elok jikalau hal ini dipertentangkan satu dengan yang lain. Akan tetapi perlu pengaturan sistem kerjanya (frame work). Yaitu : teologi tidaklah sejajar dengan ilmu pengetahuan (science), karena teologi berbicara tentang Allah dan Ciptaan-Nya dengan demikian teologi melampaui ilmu pengetaahuan (ascience). Dengan demikian, intergrasi bukan berarti ilmu teologi harus "tunduk" kepada ilmu pengetahuan (science). Atau, teologi diintervensi oleh ilmu pengetahuan (science). Teologi yang menjadi master untuk ilmu pengetahuan (science), yaitu menuntun, memberikan masukan dan memimpin ilmu pengetahuan (science) kepada kehendak Allah Pencipta.

\section{E. Simpulan}

Abad XXI yang ditandai dengan kemajuan ilmu pengetahuan dan teknologi (IPTEK), memberikan dampak seperti dua mata sisi uang yang berbeda. Satu sisi memberikan dampak postitif dan satu sisi munculnya dampak negatif. Khususnya kemajuan ilmu pengetahuan dan teknologi (IPTEK) berdampak pada studi teologi yang notabene bidang studi paling tua di dunia. Munculnya paham relativisme absolut, etiket para teolog yang tidak bersesuaian dengan Alkitab, dan minimnya pemahaman manusia abad XXI menjadi saksi kunci mundurnya minat manusia untuk mempelajari teologi.

Akan tetapi, dengan melakukan analisis historis dan teologis tentang topik ini memberikan jawaban bahwa sesungguhnya teologi adalah ratu seluruh ilmu pengetahuan. Dikatakan dia ratu bukan terletak kepada teolog atau manusia (interpretor), tetapi terletak 
kepada otoritas Alkitab dan otoritas Allah yang telah berfirman di dalam Alkitab. Teologi memberikan jawaban yang otentik, final, absolut dan sistematis tentang Allah Pencipta, manusia, alam semesta bahkan informasi tentang kehidupan dibalik kematian. Penemuan terhadap jawaban tersebut, dilakukan berdasarkan metodologi ilmiah atau kajian-kajian ilmiah yaitu kualitatif atau kuantitatif. Dimana kedua pendekatan ini digunakan juga dalam pendekatan penelitian ilmu pengetahuan dan teknologi.

Maka pada masa kini atau abad XXI, teologi dan ilmu pengetahuan (science) bukanlah sesuatu yang dipertentangkan. Tetapi diintergrasikan agar menjadi kemuliaan bagi Allah Tritunggal. Pelaku-pelaku ilmu pengetahuan (science) masa kini, haruslah memiliki "kegairahan" untuk mempelajari teologi agar mampu melihat tujuan-tujuan Allah Tritunggal dalam ilmu pengetahuan (science). Dengan demikian, segala sesuatu yang ditemukan oleh ilmu pengetahuan (science) dapat menjadi hormat dan kemulian Allah Tritunggal. 


\section{KEPUSTAKAAN}

Berkhof, Louis.,

1974 A Summary Of Cristian Doctrine, Edinburgh : Wm. B. Eerdmans Publishing Co

Cohen, Christiandy.,

2011 Sains, Teknologi \& Kebudayaan, Jurnal Teologi Stulos Volume 10 Nomor 1 April 2011, Togardo Siburian (ed), Bandung : STT Bandung

Greidanus, Sidney.,

2009 Preaching Christ From The Old Testament, Bandung : Kalam Hidup

Jacobs, Tom, dkk.,

1994 Teologi \& Parksis Komunitas Postmodern. Yogyakarta : Penerbit Kanisius

Leith, John H.,

1981 Introduction to the Reformed Tradition, Atlanta : John Knox Press

Lumintang, Stevri I.,

2006 Theologia \& Misiologia Reformed, Batu : Literatur YPPII

2015 Theology The Queen Of Science $\mathcal{E}$ The Master Of Philosophy, Jakarta : Geneva Insani Indonesia

2017 Theologia Reformasi Gereja Abad XXI, Jakarta : Geneva Insani Indonesia

Lumintang, Ramly B.,

2010 Bahaya Postmodernisme E Peranan Kredo Reformed

Mohler, Jr, R. Albert.,

2001 The Intergrity Of The Evangelical Tradition and Challenge of the Postmodern Paradigm, dalam The Challenge of Postmodernism : An Evangelical Engagement, David S. Dockery (ed), Grand Rapids : Baker

Morris, Henry M.,

1984 The Biblical Basic for Modern Science, Grand Rapids : Baker 
Pohle, Joseph.,

2015 God His Knowability, Essence And Attributes A Dogmatics Treatise, Freiburg : Aeterna Press

Sutanto, Hasan.,

1998 Hermeneutik : Prinsip \& Metode Penafsiran Alkitab, Malang : SAAT

Tracy, David.,

1981 The Analogical Imagination: Christian Theology and the Culture of Pluralism, New York : Crossroad 